\title{
Asian monsoon projection with a new large-scale monsoon definition
}

\author{
Xingang Dai $^{1} \cdot$ Yang Yang ${ }^{2,3} \cdot$ Ping Wang ${ }^{4}$ \\ Received: 11 November 2020 / Accepted: 13 November 2021 / Published online: 24 November 2021 \\ (c) The Author(s) 2021
}

\begin{abstract}
This paper focuses on Asian monsoon projection with CMIP5 multi-model outputs. A large-scale monsoon herewith is defined as a vector field of vertically integrated moisture flux from the surface to $500 \mathrm{hPa}$. Results demonstrate that the model ensemble mean underestimated the summer monsoon and overestimated slightly the winter monsoon over South Asia in both CMIP5 historical climate simulation and the monsoon projection for 2006-2015. The major of the bias is the model climate drift (MCD), which is removed in the monsoon projection for 2016-2045 under scenarios RCP4.5 for reducing the uncertainty. The projection shows that two increased moisture flows northward appeared across the Equator of Indian Ocean, the first is nearby Somalia coast toward northwestern part of South Asia, leading to excess rainfall in where the wet jet could reach, and the second starts from the equatorial Sect. $\left(80^{\circ} \mathrm{E}-100^{\circ} \mathrm{E}\right)$ toward northeastern Bay of Bengal, leading to more rainfall spreading over the northwestern coast of Indochina Peninsula. In addition, a westward monsoon flow is intensified over the Peninsula leading to local climate moisture transport belt shifted onto South China Sea, which would reduce moisture transport toward Southwest China on one hand, and transport more moisture onto the southeast coast of the China mainland. The anomalous monsoon would result in a dry climate in Northwest China and wet climate in the coast belt during summer monsoon season for the period. Besides, the Asian winter monsoon would be seemingly intensified slightly over South Asia, which would bring a dry winter climate to Indian subcontinent, Northwest China, but would be more rainfall in southeast part of Arabian Peninsula with global climate warming.
\end{abstract}

Keywords Asian monsoon projection · Bias correction · CMIP5 · Moisture transport · Monsoon rainfall · Cross-equatorial flow

\section{Introduction}

Monsoon climate can be found in many regions of the world, for instance, Asian monsoon, African monsoon, Australian monsoon, and so on (Webster 1981; Wang et al. 2004; Li and Wang 2005; Chang et al. 2018). Asian

Xingang Dai

daixg@tea.ac.cn

Ping Wang

wangp@cma.gov.cn

1 RCE-TEA, Institute of Atmospheric Physics, Chinese Academy of Sciences, Beijing 100029, China

2 College of Atmospheric Sciences, Lanzhou University, Lanzhou 730000, China

3 School of Atmospheric Sciences, Sun Yat-Sen University, Zhuhai 519082, China

4 Key Laboratory for Atmospheric Chemistry, Chinese Academy of Meteorological Sciences, Beijing 100081, China monsoon is prevailing over the South and East Asia, and about half of the world population lives in Asian monsoon zone relying on monsoon rainfall irrigation (Gadgil 2006; Wang 2006; He et al. 2007). However, the grain production is often subject to monsoon fluctuation (Todhunter et al. 1989; Mooley and Parthasarathy 1984; Nath et al. 2017). Hence, the summer monsoon rainfall prediction becomes the most important operational work in the meteorological agencies of the countries involved (Goswami and Xavier 2003; Lee et al. 2010; Fu et al. 2013; Liu et al. 2019). In fact, Asian monsoon system consists of two parts, i.e., South and East Asian monsoon subsystems (Ding and Chan 2005; Wang and Ding 2008); the former belongs to the type of tropical monsoon, and the latter is usually regarded as subtropical monsoon (Lau and $\mathrm{Li}$ 1984). South Asian monsoon is usually associated with nearly northeastward/eastward moisture transport over the subcontinent and its adjacent seas, and the latter shows a further northward moisture transport with rainfall 
spreading over the East China mainland, Korean Peninsula and Japan, as well (Dai et al. 2012; Dai and Wang 2017).

Anomalous monsoon is usually associated with global sea surface temperature changes (Joshi 2003), especially a number of regional sea surface anomaly (SSTA) patterns, such as Indian Ocean Dipole (IOD; Saji and Yamagata 2003), El Niño/Southern Oscillation (ENSO; Krishnamurthy and Goswami 2000; Fasullo and Webster 2002; Kim et al. 2012; Wang and He 2012; Wang et al. 2013), North Atlantic Oscillation (NAO; Wu et al. 2009), the Atlantic Multidecadal Oscillation (AMO), in addition to global warming (Wang et al. 2015a, b; Naidu et al. 2020; Kripalani and Kulkarni 1997; Rajeevan and McPhaden 2004; Wang and Li 2004; Achuthavarier and Krishnamurthy 2011; Kakade and Dugam 2006). The SSTA mentioned can usually lead to changes in large-scale atmospheric circulation with anomalous moisture transport over the monsoon areas (Gill 1980), which then modifies the monsoon rainfall in quantity and spatial distribution (Lee et al. 2010). Hence, various monsoon indices are designed based on atmospheric circulation dynamics or thermodynamics for describing regional monsoon variation, such as Webster-Yang Index (Webster and Yang 1992), monsoon Hadley index for South Asia monsoon (Goswami et al. 1999), and East Asian or Southeast Asian monsoon indices (Wang and Fan 1999; Li and Zeng 2003), in addition to All India Rainfall (AIR) that has become the most important monsoon index for South Asian monsoon. The monsoon indices are usually predicted every year in the countries of the monsoon zones, instead of predicting directly the whole monsoon rainfall field (Shukla and Paolin 1983; Rao et al. 2019; Huang et al. 2020).

However, such monsoon indices are usually regarded as an indicator of regional monsoon intensity that implies potential flood or drought hazard, while a large-scale monsoon pattern is often represented by the wind field on $850 \mathrm{hPa}$ (Chen et al. 2000; Ventham and Wang 2007). Nevertheless, the wind field is not always suitable for all Asian monsoon zones, especially the East Asian monsoon zone due to complex topography, such as Tibetan Plateau, the highest mountain in the surface, on one hand, and the wind field can only represent air flow pattern on pressure level in absence of important thermal or humid factors involved in the monsoon activity, on the other. Actually, the major function of large-scale monsoon is the water vapor transportation from the ocean to the land after summer monsoon onset, accompanying convective rainfall in land and over the sea. Climate statistics confirms the connection between the seasonal moisture transport and the precipitation in land (Dai and Wang 2017). Hence, vertically integrated moisture flux in low troposphere is taken herewith to represent large-scale monsoon field in this study. Both the large-scale moisture flux and the rainfall in land are taken into account in the monsoon in following monsoon projection analysis.
The Asian summer monsoon in late twentieth century has been projected by the third phase of the Coupled Model Intercomparison Project (CMIP3) model outputs (Sperber et al. 2013), while the projection for 21th century is made by fifth/ sixth phase of the Coupled Model Inter-comparison Project (CMIP5/CMIP6; Huang et al. 2020; Wang et al. 2020; Jin et al. 2020). As well known, the model outputs has become a common resource in climate projection under different emission scenarios represented by Representative Concentration Pathways (RCPs)/the Shared Socioeconomic Pathways (SSPs) (Taylor et al. 2012; Eyring et al. 2016; Chen et al. 2020a, b). However, monsoon projection is still a hard task for scientific community due to significant uncertainties existed resulting from complex physical factors, model resolution, or absence of suitable representation of large-scale monsoon above the surface.

It should be noticed that such kind of monsoon projections mentioned only refers to the monsoon rainfall changes in land, and has not yet involved the changes in large-scale monsoon pattern over tropical and subtropical zones of Asia and adjacent seas. This study tries to demonstrate the changes of large-scale Asian monsoon pattern basing on CMIP5 multimodel outputs under RCP4.5 scenarios for 2016-2045, which is somewhat like a monsoon prediction without considering RCP2.6 or RCP8.5 scenario for such a short period (30 years). The following Section 2 will introduce briefly the datasets and methods. The monsoon bias in CMIP5 historical simulation will be shown in Section 3, and Section 4 dedicates to the monsoon projection bias correction. The monsoon projection with bias correction for 2016-2045 is presented in Section 5. A short concluding remark is put in the last section with brief discussion.

\section{Data and methods}

Three datasets are used in this study, such as wind $(u, v)$, specific humidity $(q)$ on pressure levels, and surface pressure $\left(p_{s}\right)$ from reanalysis ERA-20C and ERA-Interim with resolution $1^{\circ} \mathrm{X} 1^{\circ}$ in both latitude and longitude directions (Poli et al. 2016), grid-analysis precipitation from CRU TS 4.0 in $0.5^{\circ} \times 0.5^{\circ}$ grid mesh on land (Harris et al. 2020), and 20 CMIP5 model outputs, including CMIP5 historical simulation and projection under Representative Concentration Pathway 4.5 (RCP4.5; Taylor et al. 2012). The parameters of the CMIP5 models used are listed in Table 1.

The monsoon herewith is defined as a vector represented by vertically integrated moisture flux from the surface to $500 \mathrm{hPa}$. Its formula is as follows:

$Q_{\lambda}=\frac{1}{g} \int_{500}^{p_{s}} \overline{q u} d p$ 
Table 1 Parameters of the 20 CMIP5 climate models

\begin{tabular}{|c|c|c|c|}
\hline Model name & Institution and state & Resolution & Variables \\
\hline ACCESS1-0 & CSIRO-BOM, Australia & $192 \times 145$ & $\mathrm{pr} \cdot \mathrm{u} 、 \mathrm{v} 、 \mathrm{hus}, \mathrm{psl}$ \\
\hline ACCESS1-3 & CSIRO-BOM, Australia & $192 \times 145$ & $\mathrm{pr} \cdot \mathrm{u} 、 \mathrm{v} 、 \mathrm{hus}, \mathrm{psl}$ \\
\hline BCC-CSM1-1 & BCC, China & $128 \times 64$ & $\mathrm{pr} \cdot \mathrm{u} \cdot \mathrm{v} 、 \mathrm{hus}, \mathrm{psl}$ \\
\hline BCC-CSM1-1-m & BCC, China & $320 \times 160$ & $\mathrm{pr} 、 \mathrm{u} 、 \mathrm{v} 、 \mathrm{hus}, \mathrm{psl}$ \\
\hline CanESM2 & CCCMA, Canada & $128 \times 64$ & $\mathrm{pr} 、 \mathrm{u} 、 \mathrm{v} 、 \mathrm{hus}, \mathrm{psl}$ \\
\hline CCSM4 & NCAR, U.S.A & $288 \times 192$ & $\mathrm{pr} \cdot \mathrm{u} 、 \mathrm{v} \backslash \mathrm{hus}, \mathrm{psl}$ \\
\hline CNRM-CM5 & CNRM-CERFACS, France & $256 \times 128$ & $\mathrm{pr} \cdot \mathrm{u} 、 \mathrm{v} 、 \mathrm{hus}, \mathrm{psl}$ \\
\hline CSIRO-Mk3-6-0 & CSIRO-QCCCE, Australia & $192 \times 96$ & $\mathrm{pr} \cdot \mathrm{u} 、 \mathrm{v} 、 \mathrm{hus}, \mathrm{psl}$ \\
\hline GISS-E2-H & NASA GISS, USA & $144 \times 90$ & $\mathrm{pr} \cdot \mathrm{u} 、 \mathrm{v} 、 \mathrm{hus}, \mathrm{psl}$ \\
\hline GISS-E2-H-CC & NASA GISS, USA & $144 \times 90$ & $\mathrm{pr}, \mathrm{u} 、 \mathrm{v} 、 \mathrm{hus}, \mathrm{psl}$ \\
\hline GISS-E2-R & NASA GISS, USA & $144 \times 90$ & $\mathrm{pr}, \mathrm{u} 、 \mathrm{v} 、 \mathrm{hus}, \mathrm{psl}$ \\
\hline GISS-E2-R-CC & NASA GISS, USA & $144 \times 90$ & $\mathrm{pr} \cdot \mathrm{u} 、 \mathrm{v} 、 \mathrm{hus}, \mathrm{psl}$ \\
\hline INMCM4 & INM, USSR & $180 \times 120$ & $\mathrm{pr} \cdot \mathrm{u} 、 \mathrm{v} 、 \mathrm{hus}, \mathrm{psl}$ \\
\hline IPSL-CM5A-LR & IPSL, France & $96 \times 96$ & $\mathrm{pr} \cdot \mathrm{u} \vee \mathrm{v} 、 \mathrm{hus}, \mathrm{psl}$ \\
\hline IPSL-CM5A-MR & IPSL, France & $144 \times 143$ & $\mathrm{pr} \cdot \mathrm{u} 、 \mathrm{v} 、 \mathrm{hus}, \mathrm{psl}$ \\
\hline IPSL-CM5B-LR & IPSL, France & $96 \times 96$ & $\mathrm{pr}, \mathrm{u} 、 \mathrm{v} 、 \mathrm{hus}, \mathrm{psl}$ \\
\hline MPI-ESM-LR & MPI-M, Germany & $192 \times 96$ & $\mathrm{pr} \cdot \mathrm{u}, \mathrm{v} \backslash \mathrm{hus}, \mathrm{psl}$ \\
\hline MPI-ESM-MR & MPI-M, Germany & $192 \times 96$ & $\mathrm{pr}, \mathrm{u} 、 \mathrm{v} 、 \mathrm{hus}, \mathrm{psl}$ \\
\hline NorESM1-M & NCC, Norway & $144 \times 96$ & $\mathrm{pr} \cdot \mathrm{u} \cdot \mathrm{v} 、 \mathrm{hus}, \mathrm{psl}$ \\
\hline NorESM1-ME & NCC, Norway & $144 \times 96$ & $\mathrm{pr} 、 \mathrm{u}, \mathrm{v} 、 \mathrm{hus}, \mathrm{psl}$ \\
\hline
\end{tabular}

$Q_{\varphi}=\frac{1}{g} \int_{500}^{p_{s}} \overline{q v} d p$

where $Q_{\lambda}$ and $Q_{\varphi}$ represent respectively zonal and meridian moisture flux components below $500 \mathrm{hPa}, q$ denotes specific humidity, $(u, v)$ are zonal and meridian wind components in isobaric surface (pressure level), $p$ is air pressure, the bar over them represents monthly mean, $p_{s}$ and $g$ refer respectively to the surface pressure and gravity acceleration. All datasets used are interpolated on the grids with resolution of $1^{\circ} \mathrm{X} 1^{\circ}$ in both latitude and longitude, performed by GraDS software package (http://cola.gmu.edu/grads/).

Besides, the model climate drift (MCD) will be removed as bias correction in monsoon projection for reducing its uncertainty. The MCD is removed through the difference between CMIP5 historical climate simulation and ERA-20C for 1976-2005, or the difference between the CMIP5 multimodel ensemble mean over two equivalent periods if the $\mathrm{MCD}$ is regarded as a constant during any period.

\section{Historical monsoon simulation}

\subsection{Monsoon simulation}

CMIP5 historical climate simulation provides an opportunity to test whether Asian monsoon can be reproduced by the models. Figure 1 shows that the multi-model ensemble mean of the moisture flux integrated from the surface to $500 \mathrm{hPa}$ confirms the capacity of the models that can reproduce the main characteristics of the historical Asian monsoon pattern for 1960-2005 on average. Comparison between the simulation and reanalysis ERA-20C (Fig. 1a) and (Fig. 1b) turns out that the southwest monsoon is well simulated over Arabian Sea, Indian subcontinent, and the Bay of Bengal, in addition to the northward East Asia monsoon over southeastern China mainland, Korea Peninsula, and Japan. Similarly, the model ensemble mean can also reproduce the winter monsoon pattern over Asia, such as the northwest monsoon over East Asia, strong northeast monsoon over the South China Sea, and the Bay of Bengal and Arabian Sea (Fig. 1c, d). So, CMIP5 models are of the capacity in Asian monsoon simulation during the historical time.

However, apparent bias existed in the historical monsoon simulation over Asia if compare the differences between Fig. 1a, b and Fig. 1c, d. Figure 2 shows the difference/bias pattern of the moisture flux between the CMIP5 historical simulation and its counterpart calculated from reanalysis ERA-20C for 1960-2005. Figure 2a shows that the climatemean summer monsoon simulated is usually weaker than the observation (ERA-20C) over Arabian Sea, middle and southern Indian subcontinent, northern Bay of Bengal, and East Asia except for Japan and Indochina Peninsula which monsoon simulated is stronger than the observation. In addition, the summer monsoon simulated is stronger than the observation in southeastern part of Tibetan Plateau. By contrast, the multi-model ensemble mean overestimated the winter monsoon over northern Indian Ocean, Southeast 
Fig. 1 1960-2005 vertically integrated moisture flux from the surface to $500 \mathrm{hPa}$; a, c summer and winter for reanalysis ERA-20C; b, d the two seasons for CMIP5 20-model ensemble mean; unit: $\mathrm{kg} \cdot \mathrm{m}^{-1} \cdot \mathrm{s}^{-1}$
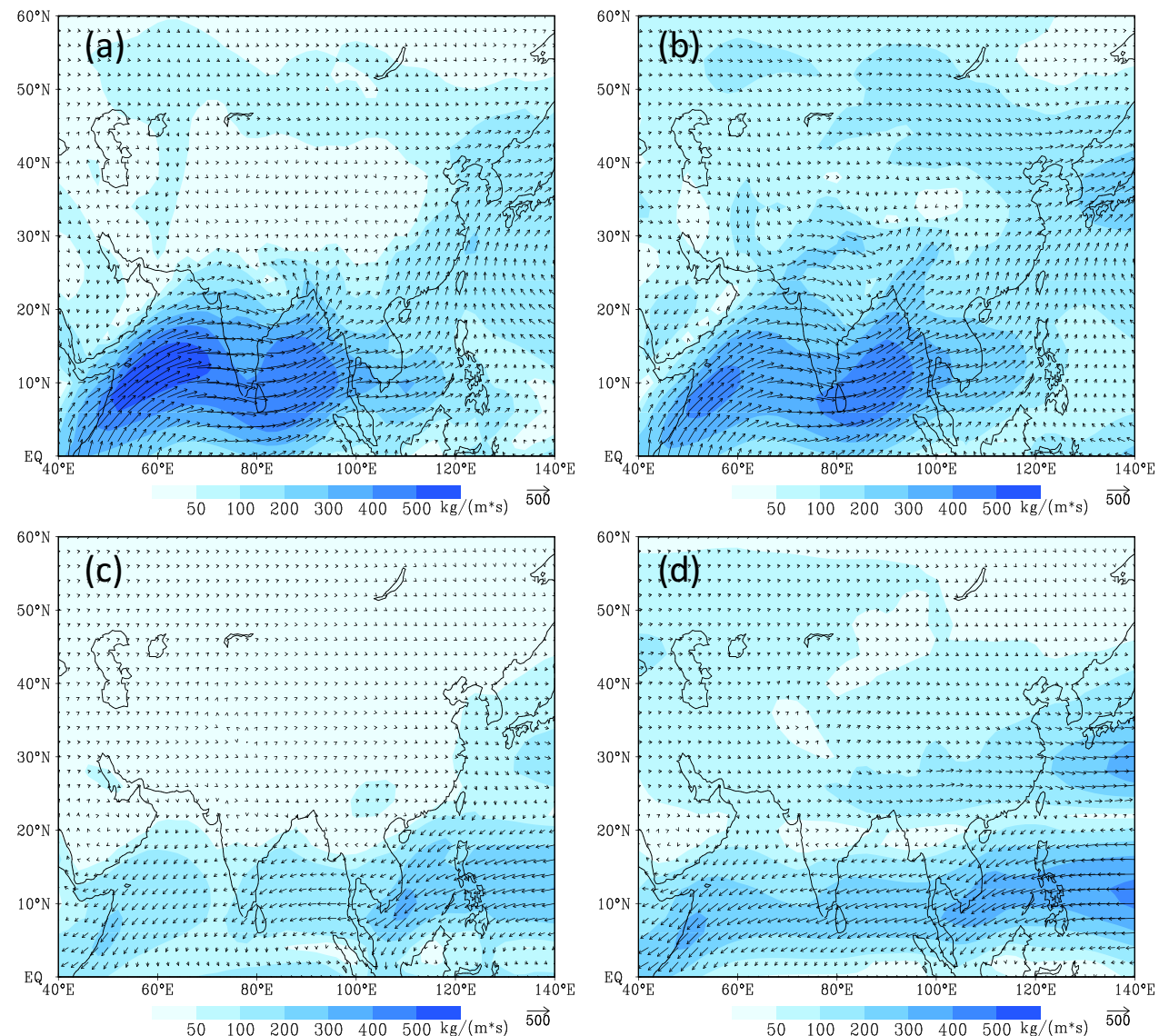

Asia, and East Asia, especially, the southern part of Indochina Peninsula, except for South China Sea where the winter monsoon is underestimated during the period (Fig. 2b).

Monsoon rainfall in land is usually taken as an important indicator of summer monsoon activity, as well known. Figure 3 a shows that the area with weak monsoon bias estimated corresponds weak rainfall estimated or negative departures of the rainfall in South Asian subcontinent, northwestern and eastern cost of Indochina Peninsula, and the southeastern coast of China mainland, Korean Peninsula, and southwestern Japan, as well, which may lead $30-40 \%$ drop rate in summer rainfall estimated by the CMIP5 multi-model ensemble in middle and northern India, resulted likely from the anticyclone pattern of the monsoon bias over the area (Fig. 2a), whereas the northeastward bias of the monsoon over the southeastern part of Tibetan Plateau and southwest part of China mainland have the rainfall overestimated by about $40 \%$ in the areas in comparison with the observation (CRUTS 4.0) during the period. Nevertheless, some of the rainfall bias seems no correspondence with the monsoon bias elsewhere, for example, the southeastward monsoon bias in North China, southern part of Central Asia, and southeastward monsoon bias in Arabian Peninsula due to probably different mechanism in precipitation formation with the monsoon zone. So, the model rainfall bias in summer season could be partly explained by the monsoon bias in Asia. It implies that large-scale rainfall bias are produced from either large-scale monsoon bias or some other factors associated with regional rainfall or models themselves, for instance, physical parameterization and model resolution, which may result in much more precipitation $(>40 \%)$ estimated in Tibetan plateau. So, both moisture flux and precipitation biases should be considered together in monsoon projection.

Nevertheless, the winter monsoon bias has less correspondence with the precipitation bias estimated by the model ensemble mean than the summer case (Fig. 2b, Fig. 3b). It implies that the winter precipitation mechanism is different from the summer one and the precipitation bias in winter season may be caused by other factors such as model resolution and physical process parameterization, other than the winter monsoon bias itself. Figure $3 \mathrm{~b}$ shows that the precipitation in winter season is overestimated by the model ensemble in most of the Asian continent except for southern part of Central Asia and Arabian Peninsula. Only less rainfall bias in Indochina peninsula corresponds to strong monsoon bias in the season. 

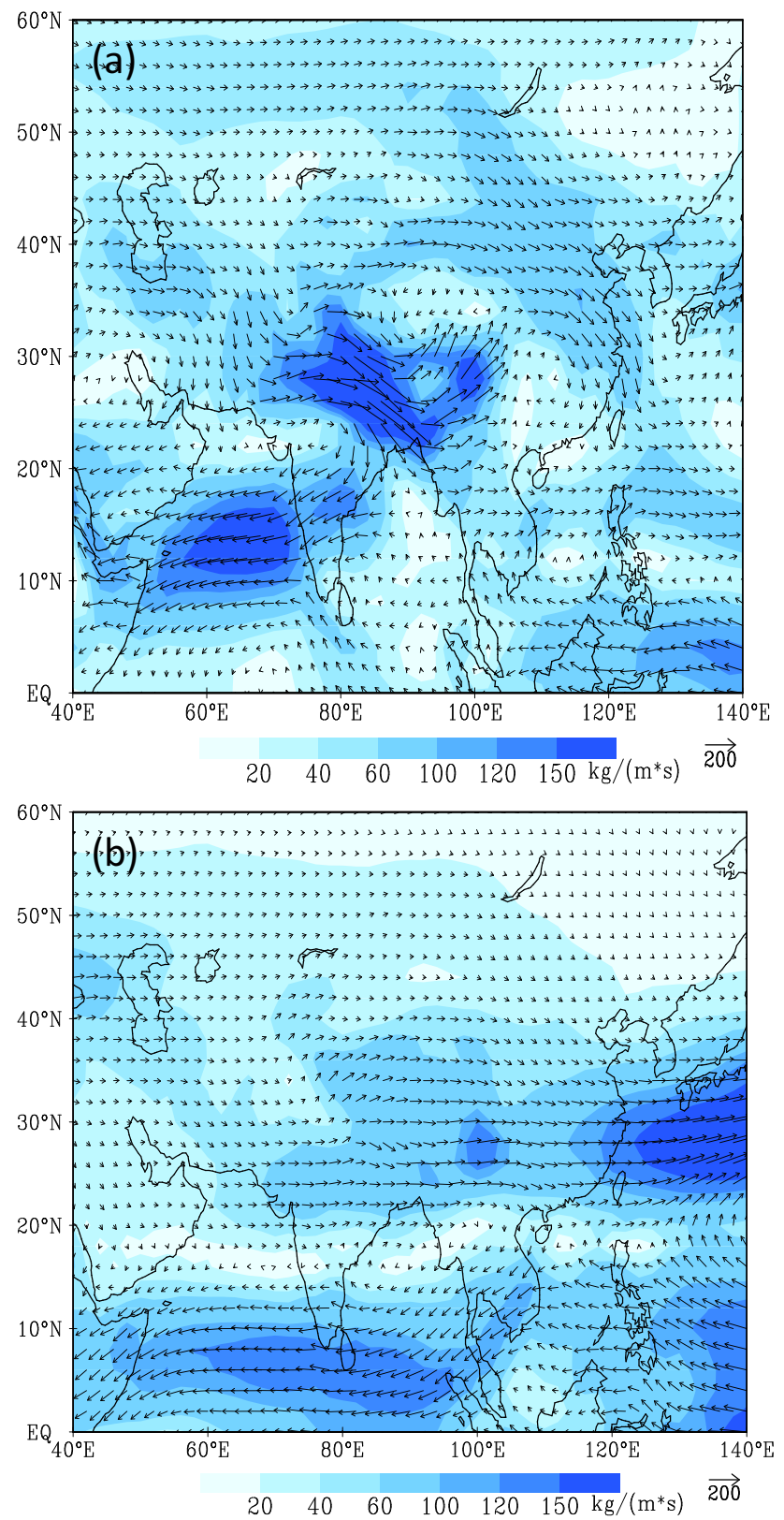

Fig. 2 Difference (bias) of the 1960-2005 Asian monsoons simulated by CMIP5 20-model ensemble mean and its counterpart from ERA20C; a summer season; b winter season; unit: $\mathrm{kg} \cdot \mathrm{m}^{-1} \mathrm{~s}^{-1}$

\section{Bias in projection}

\subsection{Monsoon projection bias}

The monsoon projection bias is obtained by CMIP5 multimodel outputs for 2006-2015 through comparing the reanalysis ERA-Interim. Figure 4a shows that the bias pattern of the projection is similar to CMIP5 historical monsoon simulation (Fig. 2a), with a weak Asian summer monsoon projected, especially in South Asia and Arabian sea, with
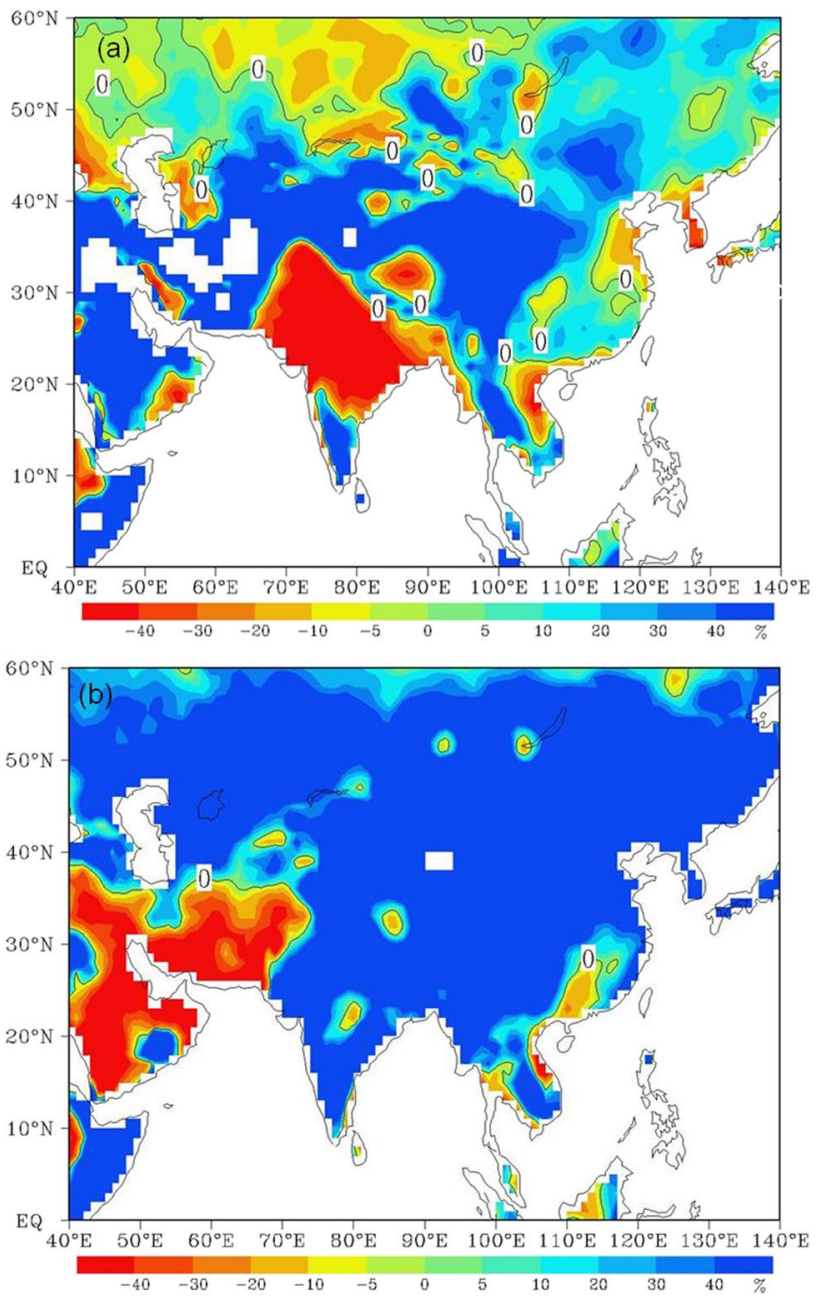

Fig. 3 Difference (bias) percentage of CMIP5 20-model ensemble mean precipitation from its counterpart of CRUTS 4.0 for 19602005; a summer season; b winter season

slightly stronger southward monsoon bias in Central Asia and North China, and a stronger northeastward monsoon bias over southern Tibetan Plateau, and a stronger northeastward bias over eastern Tibetan plateau, and a southeastward bias in South China than that of the reanalysis. On the contrary, the Asian winter monsoon projected for the period is generally stronger than the reanalysis, especially over East Asia, Indochina Peninsula, the Bay of Bengal and the eastern tropical Indian ocean of Northern Hemisphere (Fig. 4b). It implies that the monsoon projection made by CMIP5 multimodel ensemble mean has significant bias, which must be corrected before any use.

\subsection{Bias correction}

One of the simplest methods in bias correction is to remove the model climate drift (MCD) in climate projection because the MCD is usually the major of the bias (Tang et al. 2016). 
Fig. 4 Difference (bias) of the vertically integrated moisture flux between CMIP5 20-model ensemble mean and the ERAInterim for 2006-2015; a summer season; $\mathbf{b}$ winter season; unit: $\mathrm{kg} \cdot \mathrm{m}^{-1} \mathrm{~s}^{-1}$
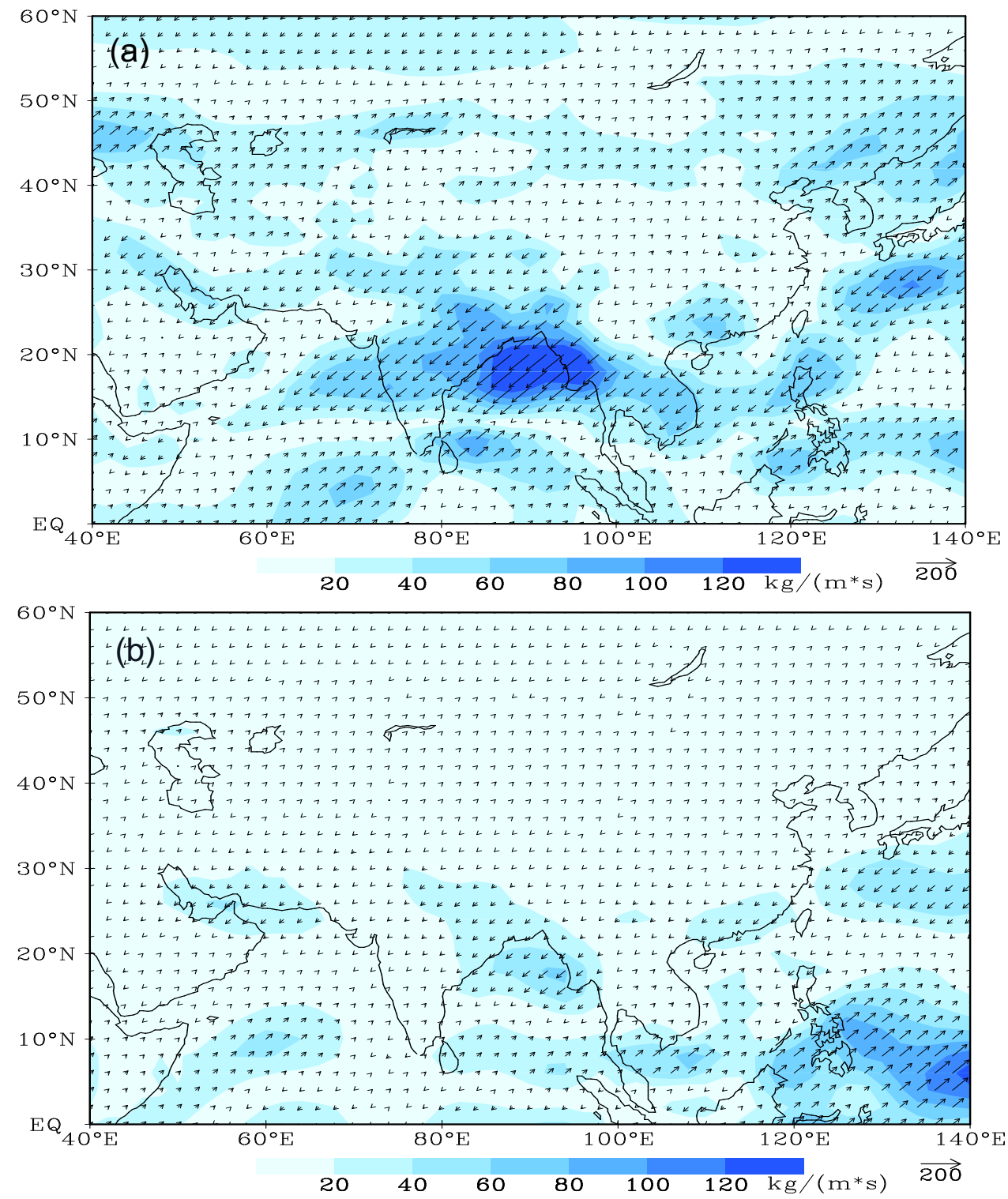

The MCD belongs to stationary or systematic bias of a model or model ensemble, and it results from various factors, such as model resolution and physical process parameterization, as well known. The MCD herewith is defined with the difference between CMIP5 multi-model historical simulation mean minus its counterpart in reanalysis ERAInterim for 1976-2005. Figure 5a shows that the summer monsoon bias becomes much weaker than that in Fig. 4 after the MCD is removed. However, weak bias is still left somewhere in the projection; for example, the summer monsoon is slightly overestimated in the eastern coast of China mainland and underestimated in Southwest China, with little bias in southeastern Tibetan Plateau, northern Bay of Bengal, Indian subcontinent and Arabian Sea if compared with Fig. 4a. Figure 5b shows a weak bias pattern of the winter monsoon resulting from the MCD removal, in which the winter monsoon bias in Fig. 4b has almost been removed in South Asia and adjacent sea, while the southward bias in Fig. 4b is turned to northward in southern part of Central Asia in Fig. 5b, and a new weak bias appeared in northeastern Bay of Bengal and southern part of South China Sea. Hence, the CMD removal can significantly reduce the bias in Asian monsoon projection made by CMIP5 multi-model ensemble mean for the period (2006-2015) although weak bias left elsewhere.

\section{Asian monsoon projection}

Asian monsoon projection for 2016-2045 is made by CMIP5 20-model ensemble mean in this study. If the MCD is regarded as a constant on a grid point at any period, it could 

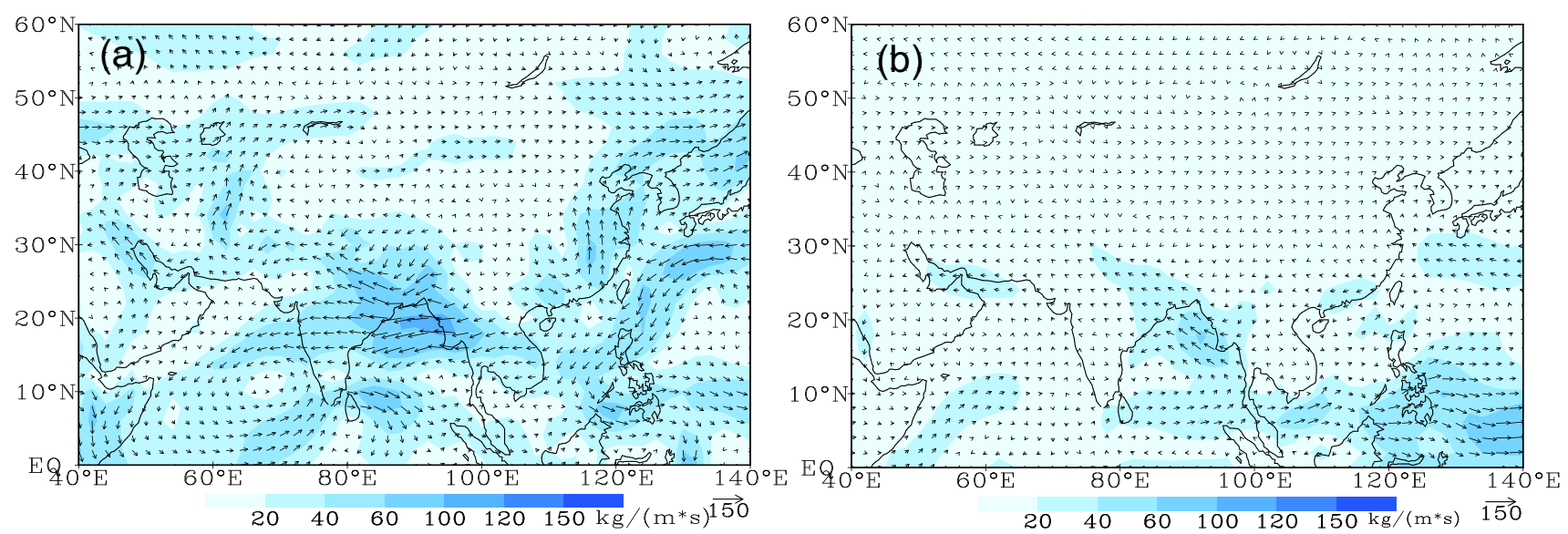

Fig. 5 Bias left for CMIP5 20-model ensemble mean after the model climate drift is removed for 2006-2015; a summer season; b winter season; unit: $\mathrm{kg} \cdot \mathrm{m}^{-1} \mathrm{~s}^{-1}$

be also removed by the difference between the monsoon averaged over two periods of 2016-2045 and 1876-2005. The difference of the mean monsoon between the periods represents the departures of the monsoon or anomalies projected from CMIP5 historical monsoon simulation for 1976-2005. So, the bias pattern left in Fig. 4 can be regarded as the reference in explaining the bias characteristics of the monsoon projection for 2016-2045 (Fig. 6).

Figure 6a shows additional three moisture flows intensified across the equator during Asian summer monsoon season for 2016-2045 in comparison with 1976-2005 (Fig. 4a), of which the western one is nearby Somalia coast directing to Pakistan dry land and northwestern part of Indian subcontinent, being favorable to increase in monsoon rainfall in the dry land, and the second is from $80^{\circ} \mathrm{E}$ to $90^{\circ} \mathrm{E}$ equator throughout northern seaboard of the Bay of Bengal, in addition to a weak one that appears over equatorial $100^{\circ} \mathrm{E}-110^{\circ} \mathrm{E}$, near by the southern end of the South China Sea in west tropical Pacific. On the other hand, intensified moisture flow eastward would appear over Indochina Peninsula leading to likely an eastward shift of the climate northward moisture flow over the Peninsula in the 30 years, which would reduce the northward moisture transport toward Southwest China mainland and cause likely a dry summer climate there for 2016-2045.

It is somewhat surprising that the climate warming under scenarios RCP4.5 would intensify the winter monsoon over Northern Indian Ocean, South Asia, and Indochina Peninsula in winter season, and, by contrast, the winter monsoon would become slightly weak over South China Sea and become a little strong in North and Northeast China mainland, Korean Peninsula, and Japan (Fig. 6b). Hence, the Asian monsoon system would probably changes in the background of moderate climate warming (RCP4.5), especially in South Asia during the projection period.
A change in large-scale monsoon pattern should likely lead to a change in precipitation pattern during the monsoon season. The departures of the 2016-2045 precipitations of the 20-model projection from 1976 to 2005 historical simulation shows that the summer rainfall would increase in northern Pakistan and northeastern Indian subcontinent with intensified moisture flow from Somalia coast to northwestern part of South Asia, which would also have more rainfall Somalia coast and the Arabian Peninsula around the Persian Gulf (Fig. 7a), which is consistent with the result that the summer monsoon area would be expending westward with climate warming due to "NHwarmer-than-SH" pattern (Wang et al. 2020; Jin et al. 2020). In addition, the rainfall projected would be also increasing in northeastern seaboard of the Bay of Bengal with strengthened moisture flow from the equator to the area (Fig. 6a). By contrast, the rainfall would decrease in Indochina Peninsula with the reduction of the summer monsoon moisture transport from the south. On the other hand, Fig. $7 \mathrm{~b}$ shows that the winter monsoon intensified would lead to a dry climate in South Asia during winter season, and increase in the southeastern Arabian Peninsula. Besides, precipitation would significantly increase in middle and, especially, high latitudes of Asian continent resulting likely from significant climate warming in the north.

If comparing Figs. 6 and 7 in detail, one may be aware of that it is not all the precipitation departures can be explained by corresponding changes in the monsoon departures due to existence of the bias in the projections and other factors that can influence the precipitation else, although a recent study with CMIP6 provided some numerical results that shows projected precipitation changes can be well explained by anomalous circulation of atmosphere (Chen et al. 2020a, b). 
Fig. 6 Departures of the Asian monsoon projection for 20162045 under RCP4.5 scenario from 1976 to 2005 historical climate simulation with CMIP5 20-model ensemble mean; a summer season; $\mathbf{b}$ winter season; unit: $\mathrm{kg} \cdot \mathrm{m}^{-1} \mathrm{~s}^{-1}$
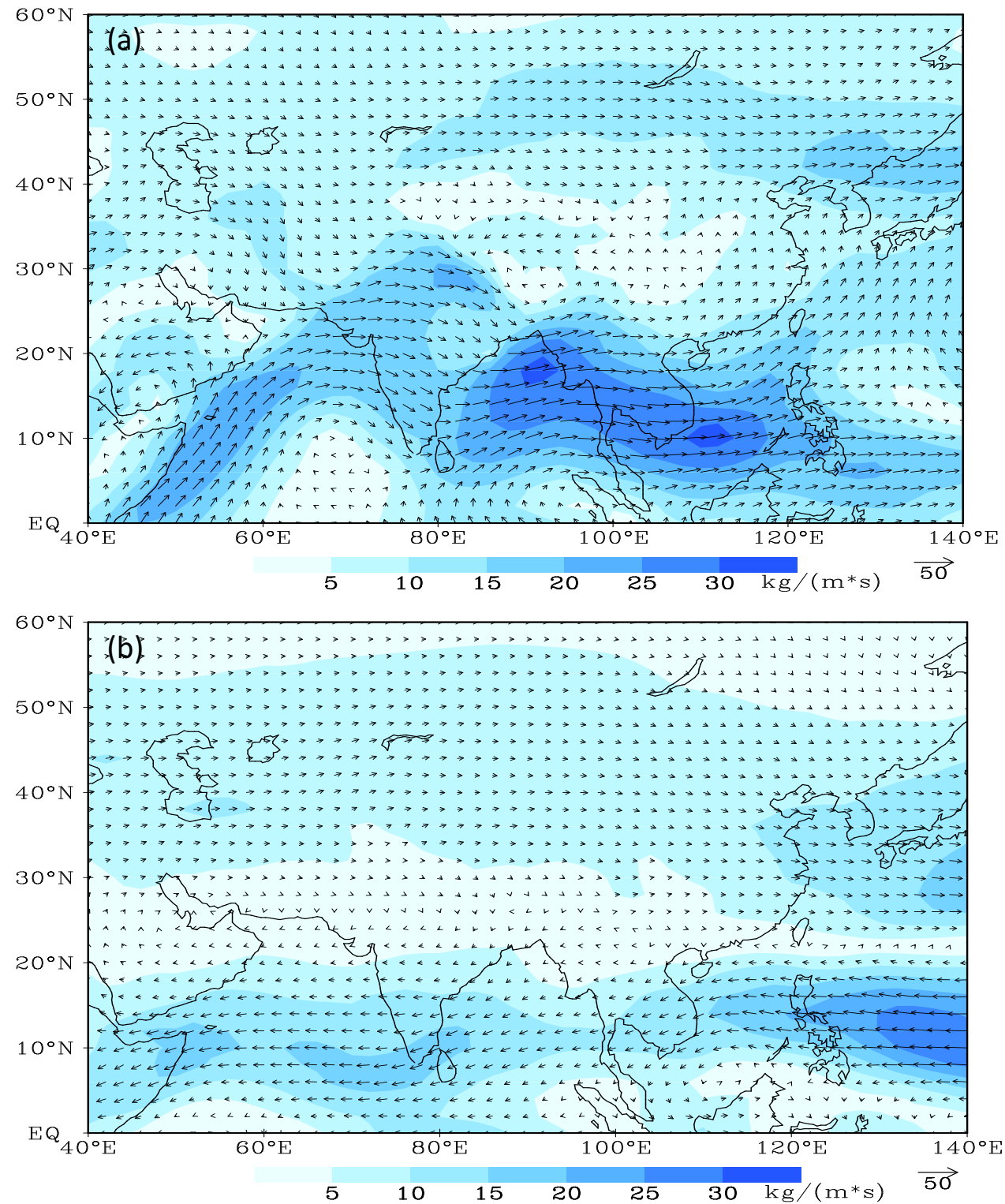

\section{Concluding remarks}

This study has analyzed the bias pattern of the Asian monsoon represented by vertically integrated moisture flux from the surface to $500 \mathrm{hPa}$ in CMIP5 historical climate simulation and projection for 2006-2015, and then made an Asian monsoon projection for 2016-2045. The main results are presented as following:

(1) CMIP5 historical monsoon simulation can approximately reproduce large-scale Asian monsoon pattern for 1960-2005

(2) The monsoon bias exists in both CMIP5 historical climate simulation and projection, which has the summer monsoon underestimated in South Asia and East Asia, and has the winter monsoon overestimated in South Asia for 1960-2005.

(3) The precipitation bias pattern corresponds approximately to the monsoon bias pattern, implying that the bias in precipitation simulation resulted partly from the monsoon simulation bias, especially in the summer season, for 1960-2005.

(4) The bias pattern of the CMIP5 monsoon projection under scenarios RCP4.5 for 2006-2015 is similar to that of the CMIP5 historical simulation for 1960-2005, which implies that the major of the bias is the modelgroup climate drift and could be removed directly.

(5) The Asian monsoon projection under scenarios RCP4.5 shows that the summer monsoon would be intensified in South Asia for 2016-2045, with two additional moisture flows northward across the equator of Indian 

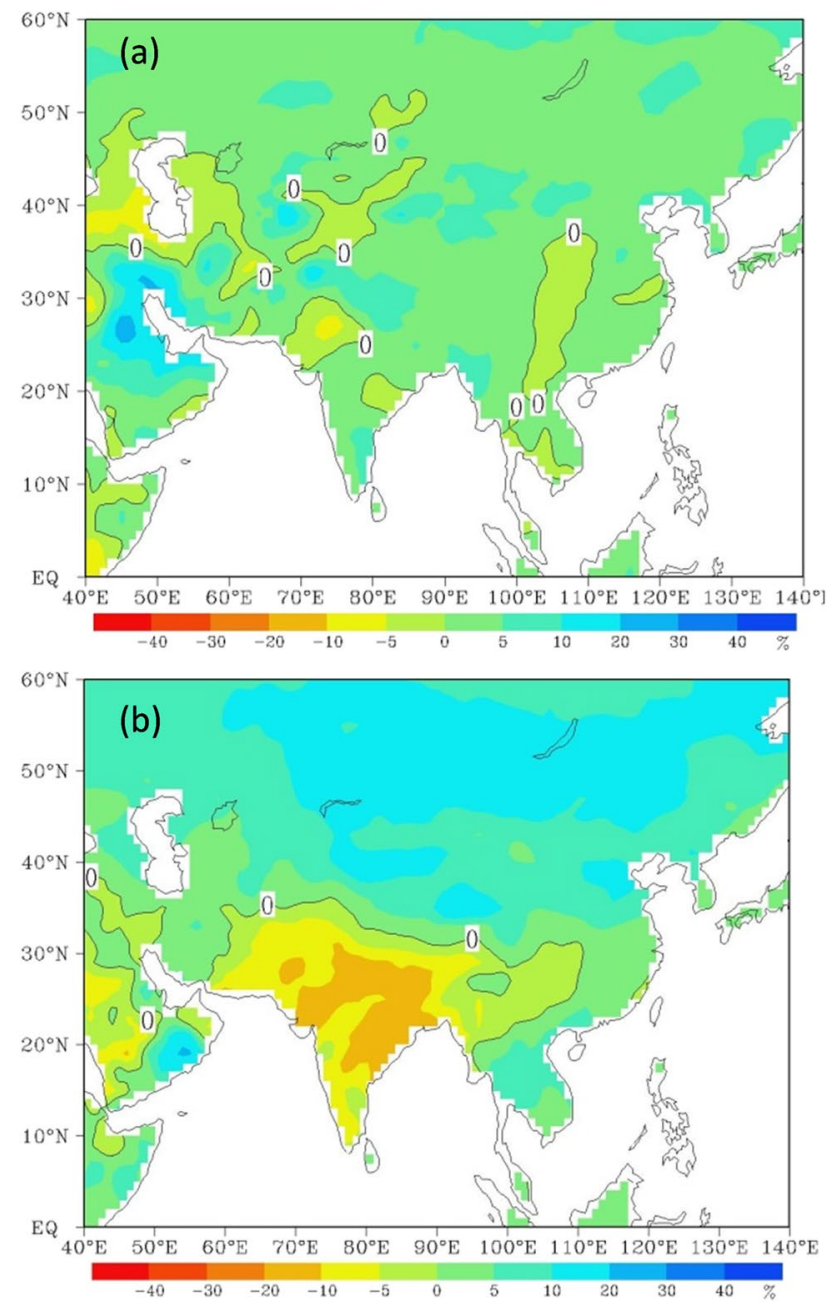

Fig. 7 Departure percentage of 2016-2045 CMIP5 precipitation projection from its historical climate simulation for 1976-2005, with CMIP5 20-model ensemble mean under scenarios RCP4.5; a summer season; $\mathbf{b}$ winter season

Ocean toward the northwestern part of South Asia and the northeastern seaboard of the Bay of Bengal, respectively, while the projection also shows that the East Asian summer monsoon would be strengthened along the southeastern coast of China mainland and declined in the southwest part of China, corresponding to potential increase in precipitation in northeastern Africa, northwestern part of South Asia and northeastern seaboard of the Indochina Peninsula, leading to a dry climate in Southwest China during the period.

(6) The projection under scenarios RCP4.5 shows that the winter monsoon would be slightly intensified over South Asia, leading to a dry winter climate in Indian subcontinent for 2016-2045. In addition, the projection also shows a potential wet winter climate in high latitude and dry climate in the south of Asian continent with climate warming.
Besides, the projection also shows that the bias still existence in the projection after the model climate drift is removed although the bias has become weak. It implies that the bias correction is still a hard work in the monsoon projection, of which the non-stationary bias should be also considered in the correction processes in the future work of monsoon projection even for the projection using CMIP6 data.

Acknowledgements The CRUTS 4.0 was downloaded from the Climate Research Unit (https://crudata.uea.ac.uk/cru/data/hrg/\#current). The reanalysis datasets of ERA-20C and ERA-Interim were obtained from the European Centre for Medium-Range Weather Forecasts (ECMWF; https://apps.ecmwf.int/datasets/). The multi-model output atmospheric circulation datasets of CMIP5 historical climate simulation and future projection was download from Coupled Model Intercomparison Project Phase 5 (CMIP5; https://esgf-node.llnl.gov/search/ cmip5/), World Climate Research Programme (WCRP). The GraDS software used for producing the figures of the study was obtained from the Center for Ocean-Land-Atmosphere Studies (COLA; http://cola. gmu.edu/grads/).

Author contribution All authors contributed to the study conception and design. Data preparation and figures were performed by Yang Yang. The first draft of the manuscript was written by Xingang Dai and Ping Wang. All authors read and approved the final manuscript.

Funding This work was partially supported by the National Natural Science Foundation of China (Grant No. 41675087, 42061144015) and National Key R\&D Program Pilot Projects of China (2016YFA0601901).

Data availability The data that support the findings of this study will be available on reasonable request, after sending e-mail to the first author (Dai Xingang).

Code availability The codes will be available on reasonable request, after sending e-mail to the first author (Dai Xingang).

\section{Declarations}

Ethics approval It is not involved.

\section{Consent to participate Yes}

\section{Consent for publication Yes}

Competing interests The authors declare no competing interests.

Open Access This article is licensed under a Creative Commons Attribution 4.0 International License, which permits use, sharing, adaptation, distribution and reproduction in any medium or format, as long as you give appropriate credit to the original author(s) and the source, provide a link to the Creative Commons licence, and indicate if changes were made. The images or other third party material in this article are included in the article's Creative Commons licence, unless indicated otherwise in a credit line to the material. If material is not included in the article's Creative Commons licence and your intended use is not permitted by statutory regulation or exceeds the permitted use, you will need to obtain permission directly from the copyright holder. To view a copy of this licence, visit http://creativecommons.org/licenses/by/4.0/. 


\section{References}

Achuthavarier D, Krishnamurthy V (2011) Role of Indian and Pacific SST in Indian summer monsoon intraseasonal variability. J Climate 24:2915-2930. https://doi.org/10.1175/2010JCLI3639.1

Chang C-P, Johnson RH, Ha K-J, Kim D, Lau GN-C, Wang B, Bell MM, Luo Y (2018) The multiscale global monsoon system: research and prediction challenges in weather and climate. Bull Amer Meteor Soc 99:ES149-ES153. https://doi.org/10.1175/ BAMS-D-18-0085.1

Chen HP, Sun J, Lin W, Xu H (2020a) Comparison of CMIP6 and CMIP5 models in simulating climate extremes. Science Bulletin 65:1415-1418. https://doi.org/10.1016/j.scib.2020.05.015

Chen T-C, Yen M-C, Weng S-P (2000) Interaction between the summer monsoons in East Asia and the South China Sea: Intraseasonal Monsoon Modes. J Atmos Sci 57:1373-1392. https://doi.org/10. 1175/1520-0469(2000)057\%3c1373:IBTSMI\%3e2.0.CO;2

Chen Z, Zhou T, Zhang L, Chen X, Zhang W, Jiang J (2020) Global land monsoon precipitation changes in CMIP6 projections. Geophy Res Let. 47:e2019GL08690. https://doi.org/10.1029/2019G L086902

Dai X-G, Wang P (2017) A new classification of Large-scale climate regimes around the Tibetan plateau based on seasonal circulation patterns. Adv Clim Chang Res 8:26-36

Dai X-G, Wang P, Zhang K-J (2012) A decomposition study of moisture transport divergence for inter-decadal change in East Asia summer rainfall during 1958-2001. Chin Phys 21:119201119208. https://doi.org/10.1088/1674-1056/21/11/119201

Ding Y, Chan JCL (2005) The East Asian summer monsoon: an overview. Meteorol Atmos Phys 89:117-142. https://doi.org/10.1007/ s00703-005-0125-z

Eyring V, Bony S, Meeh GA, Senior CA, Stevens B, Stouffer RJ, Taylor KE (2016) Overview of the coupled model intercomparison project phase 6 (CMIP6) experimental design and organization. Geosci Model Dev 9:1937-1958. https://doi.org/10.5194/ gmd-9-1937-2016

Fasullo J, Webster PJ (2002) Hydrological signatures relating the Asian summer monsoon and ENSO. J Climate 15:3082-3095. https:// doi.org/10.1175/1520-0442(2002)015\%3c3082:HSRTAS\%3e2.0. $\mathrm{CO} ; 2$

Fu X, Lee J-Y, Wang B, Wang W, Vitart F (2013) Intraseasonal forecasting of the Asian summer monsoon in four operational and research models. J Climate 26:4186-4203. https://doi.org/10. 1175/JCLI-D-12-00252.1

Gadgil S (2006) The Indian monsoon, GDP and agriculture. Econ Polit Wkly 41:4887-4895. https://doi.org/10.2307/4418949

Gill AE (1980) Some simple solutions for heat-induced tropical circulations. Q J R Meteorol Soc 106:447-462. https://doi.org/10. 1002/qj.49710644905

Goswami BN, Krishnamurthy V, Annamala H (1999) A broad-scale circulation index for the interannual variability of the Indian summer monsoon. Quart J Roy Meteor Soc 125:611-633. https://doi. org/10.1002/qj.49712555412।

Goswami BN, Xavier PK (2003) Potential predictability and extended range prediction of Indian summer monsoon breaks. Geophys Res Lett 30:1966. https://doi.org/10.1029/2003GL017810

Harris I, Osborn TJ, Jones P, Lister D (2020) Version 4 of the CRU TS monthly high-resolution gridded multivariate climate dataset. Scientific Data 7:109. https://doi.org/10.1038/s41597-020-0453-3

He J, Ju J, Wen Z, Lü J, Jin Q (2007) A review of recent advances in research on Asian monsoon in China. Adv Atmos Sci 24:972-992. https://doi.org/10.1007/s00376-007-0972-2

Huang X, Zhou T, Dai A, Li H, Li C, Chen X, Lu J, Von storch J-S, Wu B, (2020) South Asian summer monsoon projections constrained by the interdecadal Pacific oscillation. Sci Adv 6:1-10. https://doi. org/10.1126/sciadv.aay6546

Jin C, Wang B, Liu J (2020) Future changes and controlling factors of the eight regional monsoons projected by CMIP6 models. J Climate 33:3907-3926. https://doi.org/10.1175/JCLI-D-20-0236.1

Joshi I (2003) Dependence of Indian summer monsoon on SST anomalies. Proc of AP Akademi of Science 7:85-86. https://doi.org/10. 1007/s00382-011-1096-z

Kakade SB, Dugam SS (2006) Spatial monsoon variability with respect to NAO and SO. J Earth System Science 115:601-606. https://doi. org/10.1007/BF02702912

Kim H-M, Webster PJ, Curry JA, Toma VE (2012) Asian summer monsoon prediction in ECMWF System 4 and NCEP CFS v2 retrospective seasonal forecasts. Clim Dyn 39:2975-2991. https:// doi.org/10.1007/s00382-012-1470-5

Kripalani RH, Kulkarni A (1997) Climatic impact of El Nino/La Nina on the Indian monsoon: A new perspective. Weather 52:39-46. https://doi.org/10.1002/j.1477-8696.1997.tb06267.x

Krishnamurthy V, Goswami BN (2000) Indian monsoon-ENSO relationship on interdecadal timescale. J Climate 13:579-593. https:// doi.org/10.1175/1520-0442(2000)013\%3c0579:IMEROI\%3e2.0. $\mathrm{CO} ; 2$

Lee J-Y, Wang B, Kang I-S, Shukla J, Kumar A, Kug J-S, Schemm JKE, Luo J-J, Yamagata T, Fu X, Alves O, Stern B, Rosati T, Park C-K (2010) How are seasonal prediction skills related to models' performance on mean state and annual cycle? Clim Dyn 35:267-283. https://doi.org/10.1007/s00382-010-0857-4

Lau K-M, Li M-T (1984) The monsoon of East Asia and its global associations-a survey. Bull Amer Meteor Soc 65:114-125. https:// doi.org/10.1175/1520-0477(1984)065\%3c0114:TMOEAA\% 3e2.0.CO; 2

Li T, Wang B (2005) A review on the western North Pacific monsoon: Synoptic-to-interannual variabilities. Terr Atmospheric Ocean Sci 16:285-314. https://doi.org/10.3319/TAO.2005.16.2.285(A)

Liu Y, Ke Z, Ding Y (2019) Predictability of East Asian summer monsoon in seasonal climate forecast models. Int J Climatology 39:5688-5701. https://doi.org/10.1002/joc.6180

Li JP, Zeng QC (2003) A new monsoon index and the geographical distribution of the global monsoons. Adv Atmos Sci 20:299-302. https://doi.org/10.1007/s00376-003-0016-5

Mooley DA, Parthasarathy B (1984) Fluctuation in All-Indian summer monsoon rainfall during 1871-1978. Clim Change 6:287-301. https://doi.org/10.1007/BF00142477

Naidu PD, Ganeshram R, Bollasina MA, Panmei C, Nürnberg D, Donges JF (2020) Coherent response of the Indian monsoon rainfall to Atlantic multi-decadal variability over the last 2000 years. Sci Rep 10:1302. https://doi.org/10.1038/s41598-020-58265-3

Nath R, Nath D, Li Q, Chen W, Cui X (2017) Impact of drought on agriculture in the Indo-Gangetic Plain, India. Adv Atmos Sci 34:335-346. https://doi.org/10.1007/s00376-016-6102-2

Poli P, Hersbach H, Dee DP, Berrisford P, Simmons AJ, Vitart F, Laloyaux PT, David GH, Peubey C, Thépaut J-N, Trémolet Y, Hólm EV, Bonavita M, Isaksen L, Fisher M (2016) ERA-20C: an atmospheric reanalysis of the twentieth century. J Climate 29:4083-4097. https://doi.org/10.1175/JCLI-D-15-0556.1

Rajeevan M, McPhaden MJ (2004) Tropical Pacific upper ocean heat content variations and Indian summer monsoon rainfall. Geophy Res Lett 31(L18):203. https://doi.org/10.1029/2004GL020631

Rao SA et al (2019) Monsoon mission: a targeted activity to improve monsoon prediction across scales. Bull Amer Meteor Soc 100:2509-2532. https://doi.org/10.1175/BAMS-D-17-0330.1

Saji H, Yamagata T (2003) Possible impacts of Indian Ocean dipole mode events on global climate. Climate Res 25:151-169. https:// doi.org/10.3354/CR025151 
Sperber KR, Annamalai H, Kang I-S, Kitoh A, Moise A, Turner A, Wang B, Zhou T (2013) The Asian summer monsoon: an intercomparison of CMIP5 vs. CMIP3 simulations of the late 20th century. Climate Dyn 41:2711-2744. https://doi.org/10.1007/ s00382-012-1607-6

Shukla J, Paolin DAO (1983) The southern oscillation and long-range forecasting of the summer monsoon rainfall over India. Mon Wea Re 111:1830-1837. https://doi.org/10.1175/1520-0493(1983) 111\%3c1830:TSOALR\%3e2.0.CO;2

Tang Y, Li L, Dong W, Wang B (2016) Reducing the climate shift in a new coupled model. Sci Bull 61:488-494. https://doi.org/10. 1007/s11434-016-1033-y

Taylor KE, Stouffer RJ, Meehl GA (2012) An overview of CMIP5 and the experiment design. Bull Amer Meteor Soc 93:485-498. https://doi.org/10.1175/BAMS-D-11-00094.1

Todhunter PE, Mearns LO, Terjung WH, Hayes JT, Ji H-Y(1989) Effects of monsoonal fluctuations on grains in China. Part I: climatic conditions for 1961-1975. https://doi.org/10.1175/15200442(1989)002<0005:EOMFOG > 2.0.CO;2

Ventham JD, Wang B (2007) Large-scale flow patterns and their influence on the intensification rates of Western North Pacific tropical storms. Mon Wea Rev 135:1110-1127. https://doi.org/10.1175/ MWR3327.1

Wang B (2006) The Asian monsoon. Springer Praxis Books, Praxis Publishing, Chichester, p 787

Wang B, Ding Q (2008) Global monsoon: dominant mode of annual variation in the tropics. Dyn Atmos Oceans 44:165-183. https:// doi.org/10.1016/j.dynatmoce.2007.05.002

Wang B, Fan Z (1999) Choice of South Asian summer monsoon indices. Bull Amer Meteor Sci 80:629-638. https://doi.org/10.1175/ 1520-0477(1999)080\%3c0629:COSASM\%3e2.0.CO;2

Wang B, Jin C, Liu J (2020) Understanding future change of global monsoon projected by CMIP6 models. J Climate 33:6471-6489. https://doi.org/10.1175/JCLI-D-19-0993.1

Wang B, Liu J, Kim H-J, Webster PJ, Yim S-Y, Xiang B (2013) Northern hemisphere summer monsoon intensified by Mega-El Niño/ southern oscillation and Atlantic multidecadal oscillation. Proc Natl Acad Sci U S A 110:5347-5352. https://doi.org/10.1073/ pnas. 1219405110

Wang B, Li T (2004) East Asian monsoon and ENSO interactions. ed. CP Chang, World Scientific Publishing Company Book Seris 2:117-212. https://doi.org/10.1142/9789812701411_0005

Wang B, Lin H, Zhang Y, Lu M-M (2004) Definition of South China Sea monsoon onset and commencement of the East Asia summer monsoon. J Climate 17:699-710. https://doi.org/10.1175/15200442(2004)017\%3c0699:DOSCSM\%3e2.0.CO;2

Wang B, Xiang B, Li J, Webster PJ, Rajeevan MN, Liu J, Ha K-J (2015a) Rethinking Indian monsoon rainfall prediction in the context of recent global warming. Nat Commun 6:7154. https:// doi.org/10.1038/ncomms 8154

Wang HJ, Fan K, Sun J, Li S, Lin Z, Zhou G, Chen L, Lang X, Li F, Zhu Y, Chen H, Zheng F (2015b) A review of seasonal climate prediction research in China. Adv Atmos Sci 32:149-168. https:// doi.org/10.1007/s00376-014-0016-7

Wang HJ, He SP (2012) Weakening relationship between East Asian winter monsoon and ENSO after mid-1970s. Chin Sci Bull 57:3535-3540. https://doi.org/10.1007/s11434-012-5285-x

Webster PJ (1981) Monsoon. Sci Am 245:108-118

Webster PJ, Yang S (1992) Monsoon and ENSO: selectively interactive systems. Quart J Roy Meteor Soc 118:877-926. https://doi.org/ 10.1002/qj.49711850705

Wu Z, Wang B, Li J-P (2009) An empirical seasonal prediction model of the East Asian summer monsoon using ENSO and NAO. J Geophy Res 114:1-13. https://doi.org/10.1029/2009JD011733

Publisher's note Springer Nature remains neutral with regard to jurisdictional claims in published maps and institutional affiliations. 